\title{
Expression of IL-20 in synovium and lesional skin of patients with psoriatic arthritis: differential response to alefacept treatment
}

\author{
Maria C Lebre ${ }^{1,2^{*}+}$, Christina L Jonckheere ${ }^{1 \dagger}$, Maarten C Kraan ${ }^{1,3}$, Arno WR van Kuijk1, Jan D Bos ${ }^{4}$, Menno de Rie $^{4,5}$, \\ Danielle M Gerlag ${ }^{1}$ and Paul P Tak ${ }^{1,6}$
}

\begin{abstract}
Introduction: Psoriatic arthritis (PsA) is an inflammatory joint disease associated with psoriasis. Alefacept (a lymphocyte function-associated antigen (LFA)-3 Ig fusion protein that binds to CD2 and functions as an antagonist to T-cell activation) has been shown to result in improvement in psoriasis but has limited effectiveness in PsA. Interleukin-20 (IL-20) is a key proinflammatory cytokine involved in the pathogenesis of psoriasis. The effects of alefacept treatment on IL-20 expression in the synovium of patients with psoriasis and PsA are currently unknown.

Methods: Eleven patients with active PsA and chronic plaque psoriasis were treated with alefacept (7.5 mg per week for 12 weeks) in an open-label study. Skin biopsies were taken before and after 1 and 6 weeks, whereas synovial biopsies were obtained before and 4 and 12 weeks after treatment. Synovial biopsies from patients with rheumatoid arthritis (RA) $(n=10)$ were used as disease controls. Immunohistochemical analysis was performed to detect IL-20 expression, and stained synovial tissue sections were evaluated with digital image analysis. Double staining was performed with IL-20 and CD68 (macrophages), and conversely with CD55 (fibroblast-like synoviocytes, FLSs) to determine the phenotype of IL-20-positive cells in PSA synovium. IL-20 expression in skin sections ( $n=6$ ) was analyzed semiquantitatively.

Results: IL-20 was abundantly expressed in both PsA and RA synovial tissues. In inflamed PsA synovium, CD68 ${ }^{+}$ macrophages and $\mathrm{CD} 55^{+} \mathrm{FLSs}$ coexpressed IL-20, and its expression correlated with the numbers of FLSs. IL-20 expression in lesional skin of PsA patients decreased significantly $(P=0.04) 6$ weeks after treatment and correlated positively with the Psoriasis Area and Severity Index (PASI). IL-20 expression in PsA synovium was not affected by alefacept.
\end{abstract}

Conclusions: Conceivably, the relatively limited effectiveness of alefacept in PsA patients (compared with antitumor necrosis factor (TNF) therapy) might be explained in part by persistent FLS-derived IL-20 expression.

\section{Introduction}

Psoriatic arthritis (PsA) is an inflammatory joint disease associated with psoriasis, characterized by a heterogeneous clinical presentation including spinal involvement, peripheral synovitis, and enthesitis. Cellular infiltration plays an important role in the induction of inflammation in joint tissues, as well as in psoriatic skin [1].

\footnotetext{
* Correspondence: c.lebre@amc.uva.nl

† Contributed equally

'Division of Clinical Immunology and Rheumatology, Academic Medical

Center/University of Amsterdam, Amsterdam, The Netherlands

Full list of author information is available at the end of the article
}

Alefacept is a lymphocyte function-associated antigen (LFA)-3 immunoglobulin (Ig) fusion protein that binds to CD2 and functions as an antagonist to T-cell activation. Alefacept was the first of the biologic agents to be approved in the United States for the treatment of adult patients with moderate-to-severe chronic plaque psoriasis who are candidates for systemic therapy or phototherapy. This fully human fusion protein inhibits activation of memory $\mathrm{T}$ cells $\left(\mathrm{CD} 45 \mathrm{RO}^{+}\right)$, a subpopulation of lymphocytes that plays a critical role in the pathogenesis of psoriasis [2]. This therapy has been shown to be effective in patients with psoriasis 
[3], and it also has some efficacy in PsA $[4,5]$ compared with anti-TNF therapy. Clinical response, as determined by the American College of Rheumatology 20 (ACR20) response at week 24 , was achieved by a significantly greater proportion of patients receiving alefacept plus methotrexate (54\%) compared with those receiving placebo plus methotrexate (23\%), but proportions of patients achieving ACR50 and ACR70 responses at week 24 were not significantly different in a randomized, double-blind, placebo-controlled study in 185 PsA patients [5].

Interleukin-20 (IL-20) belongs to the IL-10 cytokine family. IL-20 receptor (IL-20R) and IL-20 are expressed in several normal tissue types, including the lungs, skin, and kidney [6,7]. Moreover, IL-20 has been implicated to play an important role in several autoimmune diseases that include rheumatoid arthritis (RA), lupus nephritis, and Crohn disease (reviewed in [8]). Recent reports have shown that IL-20 functions as a proinflammatory cytokine in several inflammatory diseases, of which psoriasis has been the most extensively studied $[9,10]$. $I L-20$ gene and protein expression was elevated in lesional psoriatic skin compared with normal and nonlesional skin [11-13]. Interestingly, its expression in PsA has as yet not been investigated. IL-20 is expressed mainly by activated monocytes [14]. Other sources of IL-20 are keratinocytes (KCs) $[14,15]$, maturing dendritic cells (DCs) [16], synovial fibroblasts [17], endothelial cells $[18,19]$, and renal mesangial cells [20]. IL-20 signals through two alternative receptor complexes: type I, which is composed of IL-20R1/IL-20R2 chains, and type II, which consists of an IL-22R/IL-20R2 heterodimer [21]. IL-20R1, IL-20R2, and IL-22R chains are coexpressed at high levels in the skin [7,22]. In addition, KCs [23,24], rheumatoid synovium (fibroblasts and synovial fluid cells) $[17,24,25]$, and endothelial cells [17] express IL-20R chains. The interaction between IL-20 and its receptors leads to various biologic effects that include hyperproliferation of KCs [7], production of inflammatory cytokines and chemokines by synovial fibroblasts [17] and KCs [7], neutrophil chemotaxis, and angiogenesis [17]. Recently, a role for IL-20 in osteoclast differentiation was reported [26].

Decreased expression of IL-20 in the skin has been observed after effective treatment with calcipitriol, cyclosporine [22], and infliximab [27]. Of interest, reduced IL-20 expression has also been demonstrated in the skin of patients after alefacept treatment [13], but only in those who responded clinically (12 responders versus eight nonresponders). Thus, these initial data suggest that IL-20 might serve as a biomarker associated with efficacy in patients with psoriasis. Here, we extend the findings for the skin of patients with psoriasis and demonstrate for the first time the effects of alefacept treatment on IL-20 expression in the synovium of patients with PsA. Moreover, in view of these data, it is clear that IL-20 is a key proinflammatory cytokine for both skin and synovium. The unique use of paired skin and synovium from patients with PsA (with active psoriasis) allowed us to address the question whether alefacept treatment leads to a specific tissue-response mechanism.

\section{Methods}

\section{Patients and tissue samples}

Skin and synovial biopsy specimens were obtained from patients with chronic plaque psoriasis and PsA $(n=11$ synovial biopsies; $n=6$ skin biopsies) in a prospective open-label clinical trial, as previously described [4]. Clinical characteristics have been previously reported [4]. Patients received a weekly dose of alefacept (LFA-3TIP, anti-CD2; Amevive, Biogen, San Diego, CA, USA; 7.5 $\mathrm{mg}$, intravenously) for 12 weeks. In brief, skin biopsies were taken before and after 1 and after 6 weeks, whereas synovial biopsies were taken before and 4 and 12 weeks after treatment. Synovial biopsy specimens from active RA patients (Table $1 ; n=10$ ) served as disease control group for IL-20 expression at baseline. Patient's disease activity score (DAS28), visual analogue scale (VAS) for global disease activity (scale, 0 to $100 \mathrm{~mm}$ ), swollenjoint count (SJC), tender-joint count (TJC), erythrocyte sedimentation rate (ESR), and serum levels of C-reactive protein (CRP) were used to evaluate disease activity. The study was conducted according to International Conference of Harmonization (ICH)/Declaration of Helsinki, approved by the Medical Ethics Committee of Academic Medical Center (AMC)/University of Amsterdam, and all patients gave written informed consent. Psoriasis area and severity index (PASI) was assessed as previously described [28].

\section{Synovial and skin biopsy immunohistochemical staining}

All samples were, immediately after collection, embedded en bloc in Tissue Tec OCT (Miles, Elkhart, IN, USA) and subsequently snap frozen. The frozen blocks were stored in liquid nitrogen until processed.

Table 1 Demographic and clinical characteristics of RA patients at baseline

\begin{tabular}{ll}
\hline Sex, female/male $(n)$ & RA patients \\
\hline Age in years, mean (range) & $8 / 2(10)$ \\
\hline DAS28 & $55.5(44-64)$ \\
\hline SJC, mean (range) & $4.9(2.9-6.5)$ \\
\hline TJC, mean (range) & $11.7(6-18)$ \\
\hline VAS, mean (range) & $9.8(1-16)$ \\
\hline CRP $($ mg/l), mean (range) & $22(10-32)$ \\
\hline ESR mm/h, mean (range) & $21(3-52)$ \\
\hline
\end{tabular}


Shortly before staining, $5-\mu \mathrm{m}$ sections were cut and mounted on glass slides (Star Frost; Knittelgläser, Braunschweig, Germany). The glass slides were sealed and stored at $-80^{\circ} \mathrm{C}$ until immunohistochemical analysis was performed.

In brief, after fixation with acetone, endogenous peroxidase activity was inhibited by using $0.1 \%$ sodium azide and $0.3 \%$ hydrogen peroxide in phosphate-buffered saline (PBS). The primary antibody against human IL-20 (Zymogenetics, Seattle, WA, USA) was incubated overnight at $4^{\circ} \mathrm{C}$ followed by secondary antibody affinity-purified horseradish peroxidase (HRP)-conjugated goat anti-mouse (Dako Cytomation, Glostrup, Denmark) for 30 minutes, followed by subsequent incubation with biotinylated tyramide (Perkin Elmer, Boston, MA, USA) for 30 minutes and HRP-conjugated streptavidin for 30 minutes. HRP activity was detected by using hydrogen peroxide as substrate and amino ethylcarbazole (AEC; SK-4200; Vector Laboratories, Burlingame, CA, USA) as dye. With this procedure, IL-20-positive cells stained red. Slides were counterstained with Mayer hematoxylin (Merck, Darmstadt, Germany) and, after washing with distilled water, mounted in Kayser glycerol gelatin (Merck).

To identify IL-20-expressing cells in PsA synovial tissue, double staining was performed by using anti-IL-20 antibody together with FITC-labeled anti-CD55 (M2192; Sanquin Reagents, Amsterdam, The Netherlands) or FITC-labeled anti-CD68 (clone KP1; Dakocytomation). Fixation and blocking endogenous peroxidase activity was performed as stated earlier. The primary antibody against human IL-20 (Zymogenetics) was incubated overnight at $4^{\circ} \mathrm{C}$ followed by secondary antibody affinity-purified horseradish peroxidase (HRP)-conjugated goat anti-mouse (Dako Cytomation) for 30 minutes, and subsequent incubation with biotinylated tyramide (Perkin Elmer) for 30 minutes and HRP-conjugated streptavidin for $30 \mathrm{~min}$ utes. After a blocking step of 15 minutes with $10 \%$ mouse serum (Sanquin Reagents), FITC-labeled anti-CD55 or FITC-labeled anti-CD68 was added to the sections and incubated for 1 hour at room temperature. Then the sections were incubated for 30 minutes with rabbit anti-FITC followed by alkaline phosphatase-conjugated swine antirabbit secondary antibodies (both from Dako Cytomation). HRP activity was detected as stated earlier. Alkaline phosphatase activity was detected by using the Alkaline Phosphatase Substrate III kit (SK-5300; Vector Laboratories). With this procedure, IL-20-positive cells stained red, CD55- or CD68-positive cells stained blue, and doublepositive cells stained purple.

\section{Quantification of IL-20-expressing cells in skin and synovium}

Skin biopsy specimens were scored semiquantitatively for IL-20 expression on a 5 -point scale by two independent observers who were not aware of the clinical data. The scoring methods were described previously [29]. In brief, a score of 0 represented minimal staining, whereas a score of 4 represented widespread expression of IL-20 in this case. Individual readings were identical or differed by only 1 point. Minor differences between the observers were resolved by mutual agreement.

Quantification of IL-20-expressing cells in PsA and RA synovial tissues was performed with computer-assisted image analysis, as previously described [30]. The same holds true for CD68 and CD55 quantification. In brief, after immunohistochemical staining, all coded sections (one section per patient per time point) were randomly analyzed (18 high-power fields from different parts of the section were analyzed; for example, the mean of the 18 high-power fields was calculated). The images of the highpower fields were analyzed by using the Qwin analysis system (Leica, Cambridge, UK). Positive staining of CD68 and CD55 was expressed as positive cells $/ \mathrm{mm}^{2}$. Positive staining for IL-20 was expressed as integrated optical density $\left(\mathrm{IOD} / \mathrm{mm}^{2}\right)$.

\section{Statistical analysis}

SPSS version 15.0 for Windows (SPSS, Chicago, IL, USA) was used for statistical analysis. The Wilcoxon signed ranks test was used for comparison of nonparametric variables in related samples, and the Mann-Whitney $U$ test was used for comparison of nonparametric variables in independent samples. Correlations between synovial IL-20 expression and disease activity score 28 (DAS28), synovial CD4, CD8, CD68, and CD55 were analyzed with Spearman rank correlation. Correlations between skin IL-20 and PASI were analyzed with Spearman rank correlation.

\section{Results}

\section{Expression of IL-20 in PsA and RA synovia}

First we analyzed whether IL-20 expression in PsA and RA synovia differ from each other. IL-20 was expressed in the intimal lining layer, in the synovial sublining, and on endothelium in both PsA and RA patients (Figure 1A). Digital image analysis of synovial tissue demonstrated clear IL-20 expression with comparable overall scores in both patient groups (median Integrated Optical Density (IOD) (range)): PsA, 60,064 (1,588 to 567,696); RA, 68,554 $(1,171$ to 530,218$)$ (Figure 1B). Double staining of inflamed PsA synovium showed that $\mathrm{CD} 68^{+}$macrophages and $\mathrm{CD}^{+} 5^{+}$FLS coexpress IL-20 (Figure 1C).

\section{Alefacept treatment does not affect IL-20 expression in PsA synovium}

As previously described, alefacept treatment resulted in clinical improvement and in a reduction of $\mathrm{CD} 4^{+} \mathrm{T}$ cells and $\mathrm{CD} 68^{+}$macrophages in the synovial infiltrate [4]. Despite the clinical improvement and change in cellular 
A
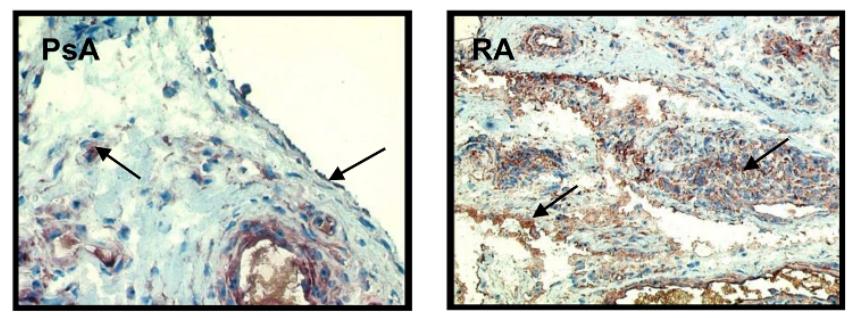

C

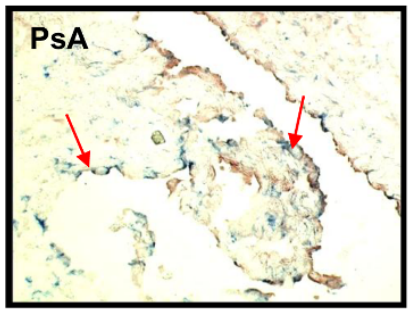

IL-20/CD68

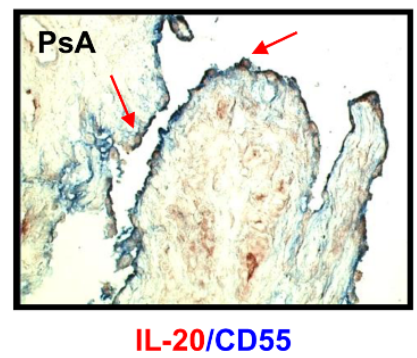

B

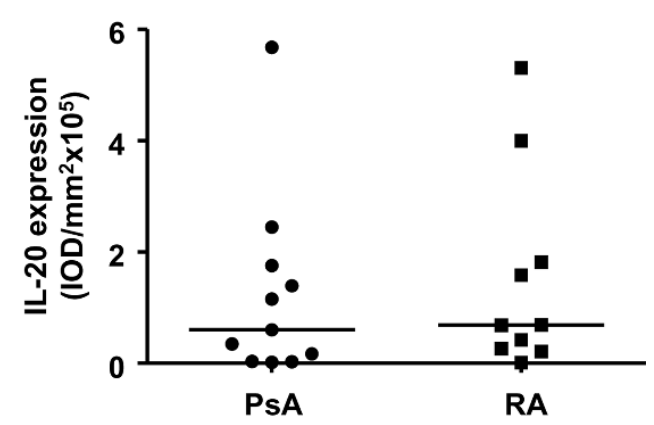

Figure 1 IL-20 is expressed in PsA and RA synovial tissues. (A) Representative immunohistochemical staining of baseline IL-20 expression in synovial tissue from PsA and RA patients. Arrows indicate expression of IL-20 in both lining and sublining. (B) Quantification of IL-20 expression in RA and PsA synovial tissues. Results are shown as median IOD (integrated optical density) $/ \mathrm{mm}^{2} \times 10^{5}$ of 10 patients with RA and 11 patients with PsA. (C) Doubleimmunohistochemistry stainings of IL-20 (red) and CD68 ${ }^{+}$macrophages (blue) and CD55 FLS (blue) in PsA synovium. A representative double immunostaining of PSA synovium from one patient is shown. Arrows indicate double-positive cells. Original magnification, $\times 200$. CRP, C-reactive protein; DAS28, disease activity score; ESR, erythrocyte sedimentation rate; SJC, swollen-joint count; TJC, tender-joint count; VAS, visual analogue scale (100 mm).

infiltrate [4], no change was found in IL-20 expression in the synovium before and after treatment (Figure 2A and 2B). As $\mathrm{CD} 8^{+}$macrophages and $\mathrm{CD} 55^{+}$FLSs express IL20 , we investigated whether the levels of synovial IL-20 were associated with the numbers of these cells present in synovial tissue. Although no correlation was present between the levels of IL-20 and the numbers of both total $\mathrm{CD}_{68}{ }^{+}$and sublining $\mathrm{CD}^{+} 8^{+}$macrophages (data not shown), the levels of IL-20 were positively correlated with the numbers of $\mathrm{CD}^{+} 5^{+}$FLSs $(r=0.4238 ; P=$ 0.0196). In addition, the levels of synovial IL-20 expression were not correlated with disease-activity parameters: DAS28, C-reactive protein (CRP), and erythrocyte sedimentation rate (ESR) (data not shown).

\section{Decreased IL-20 expression in PsA skin lesions after alefacept treatment}

In contrast to findings in the synovium, IL-20 expression in PsA lesional skin was significantly decreased $(P$ $=0.04$ ) 6 weeks after alefacept treatment (Figure 3A and 3B). IL-20 expression in PsA lesional skin was positively correlated with disease activity (PASI score) $r=0.5062$; $P=0.031$ (Figure 3C).

\section{Discussion}

Here we show that IL-20 is expressed in PsA synovium, similar to the levels in RA synovium. In PsA inflamed synovium, both $\mathrm{CD}^{+} 8^{+}$macrophages and $\mathrm{CD} 55^{+}$FLSs coexpress IL-20. This study is the first to investigate the effects of alefacept treatment on IL-20 expression in paired synovial tissue and psoriatic lesional skin of patients with both PsA and psoriasis. Whereas IL-20 expression in PsA synovium was not affected by alefacept treatment, its expression in lesional skin was significantly decreased after this treatment. In addition, in psoriatic lesional skin, IL-20 expression was positively correlated with disease activity (PASI) at baseline and after treatment. In contrast, synovial IL-20 expression was not correlated with disease-activity parameters (DAS28, CRP, ESR; data not shown). The observed expression of IL-20 in both PsA and RA synovial tissues is consistent with previous observations showing comparable levels of this proinflammatory cytokine in synovial fluid of patients with RA compared with those with spondyloarthritides, including PsA [24]. These data suggest that synovial IL-20 expression is a feature of various inflammatory rheumatic diseases.

As reported for RA $[17,24]$, we found that both macrophages and FLSs are a source of IL-20 in the synovium of PsA patients. The exact biologic effects of synovial IL-20 have yet to be determined, but it is tempting to speculate that this cytokine might affect cells present in inflamed synovium. Consistent with this notion, it was reported that IL-20 induced the production of IL- 6 and IL- 8 and 


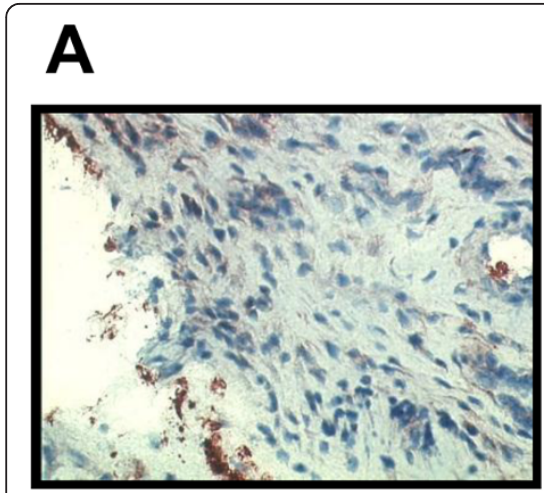

Baseline

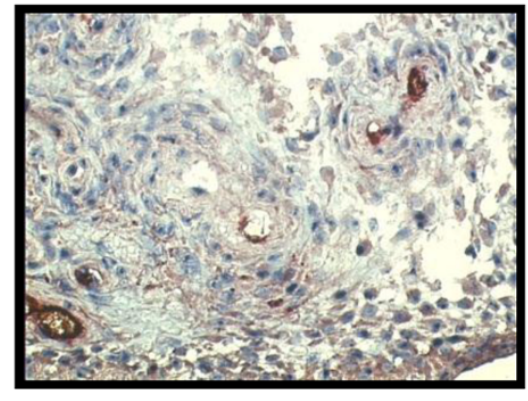

Week 4

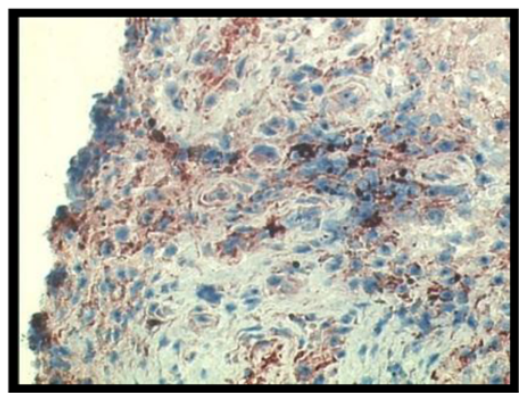

Week 12
B

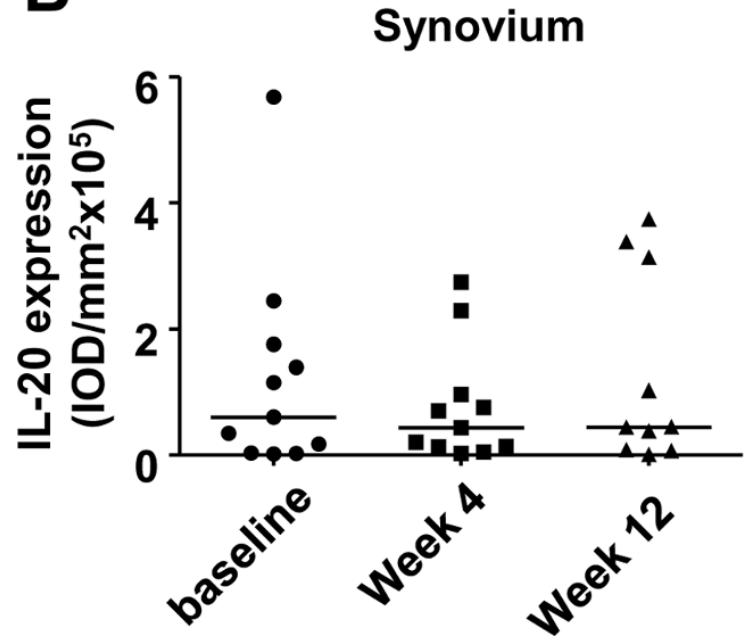

C

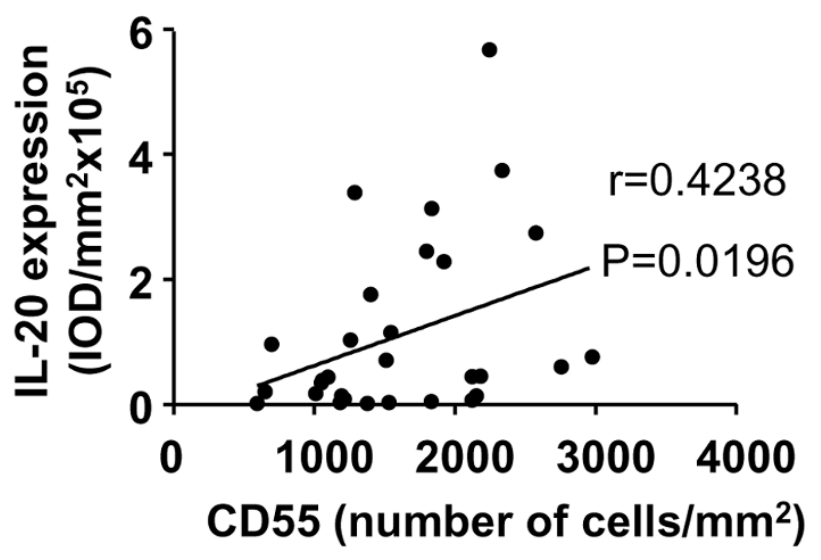

Figure 2 Alefacept treatment does not affect IL-20 expression in PsA synovium. (A) Representative immunohistochemical staining of IL-20 in the synovium of a PSA patient. (B) Quantification of IL-20 expression in PsA synovium. Results are shown as median IOD (integrated optical density) $/ \mathrm{mm}^{2} \times 10^{5}$ of 11 patients with PsA. (C) Correlation between the expression of IL-20 and the number of CD55 ${ }^{+}$FLSs in PsA synovium. Original magnification, $\times 200$. Each dot represents the mean of the 18 high-power fields per patient per time point. CRP, C-reactive protein; DAS28, disease activity score; ESR, erythrocyte sedimentation rate; SJC, swollen-joint count; TJC, tender-joint count; VAS, visual analogue scale (100 mm).

monocyte chemoattractant protein 1 by FLSs [17]. A considerable amount of evidence suggests that FLSs are key cells that contribute to RA pathogenesis. In this way, IL-20 could play a role in perpetuating the inflammatory process by promoting the release of inflammatory cytokines and chemokines at the site of inflammation [17].

Alefacept treatment resulted in changes in synovial inflammation in PsA patients that included a significant reduction in $\mathrm{CD}_{4}^{+}$lymphocytes, $\mathrm{CD}^{+}$lymphocytes, and $\mathrm{CD}^{+} 8^{+}$sublining macrophages [4], supporting the hypothesis that $\mathrm{T}$ cells orchestrate synovial inflammation in PsA. However, the expression of synovial IL-20 was not affected by alefacept treatment, in contrast to the findings in the skin. This may be explained by the fact that alefacept treatment did not affect the numbers of intimal macrophages or the CD55 ${ }^{+}$FLSs [4]; both cell types are sources of IL-20, but only the numbers of CD $55^{+}$FLSs were positively correlated with the levels of synovial IL-20. Together, the data show that alefacept treatment does not affect the major cellular source of IL-20 in the synovium (FLSs), in contrast to the findings in the skin. Of note, alefacept treatment has been abandoned as a treatment of PsA, consistent with its limited clinical efficacy compared with TNF- $\alpha$-targeted therapies [31-33]. As discussed, alefacept treatment was associated with decreased IL-20 expression in lesional psoriatic skin. As alefacept targets $\mathrm{T}$ cells, it is tempting to speculate that in the skin, $\mathrm{T}$ cells are involved in the proximal regulation of IL-20. It is well established that in psoriasis skin, cross-talk between infiltrating $\mathrm{T}$ cells and resident $\mathrm{KCs}$ is 


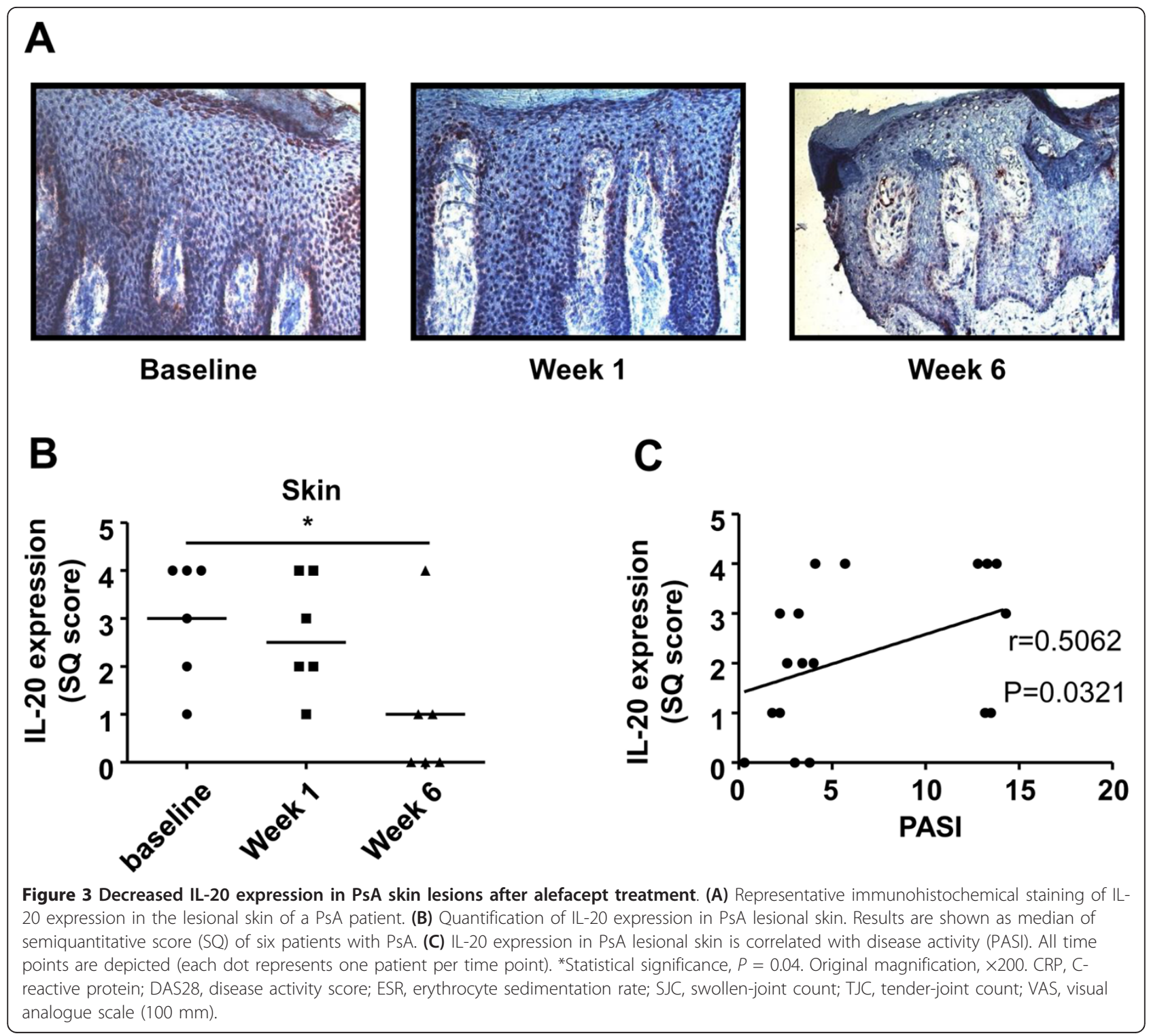

involved in disease pathogenesis [34]. In addition, it was recently reported that $\mathrm{T}$ cell-derived cytokines (IL-17 and IL-22) mediate IL-20 production by KCs [35]. Thus, in psoriatic skin of PsA patients, alefacept may affect KCderived IL-20 by decreasing the number of infiltrating $\mathrm{T}$ cells that interact with $\mathrm{KCs}$.

\section{Conclusions}

IL-20 has been implicated in several inflammatory diseases. The results presented here show that IL-20 is expressed in psoriatic skin lesions and synovial tissue from patients with both psoriasis and PsA. It remains to be established whether the observed effects of alefacept are specific for IL-20 or also are seen with other members of the IL-10 subfamily (IL-19 and IL-24). Conceivably, the limited effectiveness of alefacept in PsA patients compared with anti-TNF therapy [31-33] might be explained in part by persistent IL-20 production by sublining macrophages and FLSs in the synovium.

\section{Abbreviations}

ACR: American College of Rheumatology; AMC: Academic Medical Center; CRP: C-reactive protein; DAS28: disease activity score; DC: dendritic cell; ESR: erythrocyte sedimentation rate; FLS: fibroblast-like synoviocyte; HRP: horseradish peroxidase; ICH: International Conference of Harmonization; IL20: interleukin-20; IL-20R: IL-20 receptor; IOD: integrated optical density; KC: keratinocytes; LFA-3: Iymphocyte function-associated antigen-3; PASI: Psoriasis Area and Severity Index; PsA: psoriatic arthritis; RA: rheumatoid arthritis; SJC: swollen-joint count; TJC: tender-joint count; TNF: tumor necrosis factor; VAS: visual analogue scale.

\section{Acknowledgements}

The authors thank G. Appel (Academic Medical Centre/University of Amsterdam, Department of Dermatology, Amsterdam, The Netherlands) and Man-Wai Tang (Academic Medical Centre/University of Amsterdam, Division 
of Clinical Immunology \& Rheumatology, Amsterdam, The Netherlands) for helping with collection of patient demographics and Dr. T. Smeets (Academic Medical Centre/University of Amsterdam, Division of Clinical Immunology \& Rheumatology, Amsterdam, The Netherlands) for performing synovial immunohistochemistry staining.

\section{Author details}

'Division of Clinical Immunology and Rheumatology, Academic Medical Center/University of Amsterdam, Amsterdam, The Netherlands. ${ }^{2}$ Department of Experimental Immunology, Academic Medical Center/University of Amsterdam, Amsterdam, The Netherlands. ${ }^{3}$ AstraZeneca, Mölndal, Sweden. ${ }^{4}$ Department of Dermatology, Academic Medical Center/University of Amsterdam, Amsterdam, The Netherlands. ${ }^{5}$ Department of Dermatology, Erasmus Medical Center, Rotterdam, The Netherlands. ${ }^{6}$ Academic Medical Center/University of Amsterdam and GlaxoSmithKline, Stevenage, UK.

\section{Authors' contributions}

All authors meet the criteria for authorship and more specifically for contributorship statement: $\mathrm{MCL}$ and $\mathrm{CL}$ analyzed and interpreted the data and wrote the article under the close supervision of PPT and thereby take responsibility for this work. MCK, AWVK, JDB, MdR, DMG, and PPT conceived the study and participated in its design and coordination. MCK and AWVK collected and supplied the data. All authors agreed to publish this work and critically reviewed the article. Conception and design of this work were discussed with all authors.

\section{Competing interests}

The authors declare that they have no competing interests.

Received: 2 April 2012 Revised: 3 June 2012

Accepted: 24 September 2012 Published: 24 September 2012

\section{References}

1. Kaltwasser JP: Leflunomide in psoriatic arthritis. Autoimmun Rev 2007, 6:511-514

2. Heffernan MP, Leonardi CL: Alefacept for psoriasis. Semin Cutan Med Surg 2010, 29:53-55.

3. Krueger GG, Papp KA, Stough DB, Loven KH, Gulliver WP, Ellis CN: A randomized, double-blind, placebo-controlled phase III study evaluating efficacy and tolerability of 2 courses of alefacept in patients with chronic plaque psoriasis. J Am Acad Dermatol 2002, 47:821-833.

4. Kraan MC, van Kuijk AW, Dinant HJ, Goedkoop AY, Smeets TJ, de Rie MA, Dijkmans BA, Vaishnaw AK, Bos JD, Tak PP: Alefacept treatment in psoriatic arthritis: reduction of the effector $T$ cell population in peripheral blood and synovial tissue is associated with improvement of clinical signs of arthritis. Arthritis Rheum 2002, 46:2776-2784.

5. Mease PJ, Reich K: Alefacept with methotrexate for treatment of psoriatic arthritis: open-label extension of a randomized, double-blind, placebocontrolled study. J Am Acad Dermatol 2009, 60:402-411.

6. Wei CC, Hsu YH, Li HH, Wang YC, Hsieh MY, Chen WY, Hsing CH, Chang MS: IL-20: biological functions and clinical implications. J Biomed Sci 2006, 13:601-612.

7. Blumberg H, Conklin D, Xu WF, Grossmann A, Brender T, Carollo S, Eagan M, Foster D, Haldeman BA, Hammond A, Haugen H, Jelinek L, Kelly JD, Madden K, Maurer MF, Parrish-Novak J, Prunkard D, Sexson S, Sprecher C, Waggie K, West J, Whitmore TE, Yao L, Kuechle MK, Dale BA, Chandrasekher YA: Interleukin 20: discovery, receptor identification, and role in epidermal function. Cell 2001, 104:9-19.

8. Leng RX: IL-19, IL-20 and IL-24: potential therapeutic targets for autoimmune diseases. Expert Opin Ther Targets 2011, 15:119-126.

9. Stenderup K, Rosada C, Worsaae A, Clausen JT, Norman DT: Interleukin-20 as a target in psoriasis treatment. Ann N Y Acad Sci 2007, 1110:368-381.

10. Stenderup K, Rosada C, Worsaae A, Gnaes-Hansen F, Steiniche T, Hasselager E, Iversen LF, Zahn S, Woldike H, Holmberg HL, Romer J, Kragballe K, Clausen JT, Dam TN: Interleukin-20 plays a critical role in maintenance and development of psoriasis in the human xenograft transplantation model. Br J Dermatol 2009, 160:284-296.

11. Wei CC, Chen WY, Wang YC, Chen PJ, Lee JY, Wong TW, Chen WC, Wu JC, Chen GY, Chang MS, Lin YC: Detection of IL-20 and its receptors on psoriatic skin. Clin Immunol 2005, 117:65-72.
12. Otkjaer K, Kragballe K, Funding AT, Clausen JT, Noerby PL, Steiniche T, Iversen $L:$ The dynamics of gene expression of interleukin-19 and interleukin-20 and their receptors in psoriasis. $\mathrm{Br} J$ Dermatol 2005, 153:911-918.

13. Wang F, Lee E, Lowes MA, Haider AS, Fuentes-Duculan J, Abello MV, Chamian F, Cardinale I, Krueger JG: Prominent production of IL-20 by CD68+/CD11c+ myeloid-derived cells in psoriasis: gene regulation and cellular effects. J Invest Dermatol 2006, 126:1590-1599.

14. Wolk K, Kunz S, Asadullah K, Sabat R: Immune cells as sources and targets of the IL-10 family members? J Immunol 2002, 168:5397-5402.

15. Sabat $R$, Wolk K: Research in practice: IL-22 and IL-20: significance for epithelial homeostasis and psoriasis pathogenesis. J Dtsch Dermatol Ges 2011, 9:518-523.

16. Wolk K, Witte K, Witte E, Proesch S, Schulze-Tanzil G, Nasilowska K, Thilo J, Asadullah $\mathrm{K}$, Sterry W, Volk HD, Sabat R: Maturing dendritic cells are an important source of IL-29 and IL-20 that may cooperatively increase the innate immunity of keratinocytes. J Leukoc Biol 2008, 83:1181-1193.

17. Hsu YH, Li HH, Hsieh MY, Liu MF, Huang KY, Chin LS, Chen PC, Cheng HH, Chang MS: Function of interleukin-20 as a proinflammatory molecule in rheumatoid and experimental arthritis. Arthritis Rheum 2006, 54:2722-2733.

18. Hammer T, Tritsaris K, Hubschmann MV, Gibson J, Nisato RE, Pepper MS, Dissing S: IL-20 activates human lymphatic endothelial cells causing cell signalling and tube formation. Microvasc Res 2009, 78:25-32.

19. Hsieh MY, Chen WY, Jiang MJ, Cheng BC, Huang TY, Chang MS: Interleukin-20 promotes angiogenesis in a direct and indirect manner. Genes Immun 2006, 7:234-242.

20. Li HH, Chen HH, Sun KH, Wei CC, Li CF, Chen WC, Wu WM, Chang MS: Interleukin-20 targets renal mesangial cells and is associated with lupus nephritis. Clin Immunol 2008, 129:277-285.

21. Wegenka UM: IL-20: biological functions mediated through two types of receptor complexes. Cytokine Growth Factor Rev 2010, 21:353-363.

22. Romer J, Hasselager E, Norby PL, Steiniche T, Thorn CJ, Kragballe K: Epidermal overexpression of interleukin-19 and -20 mRNA in psoriatic skin disappears after short-term treatment with cyclosporine a or calcipotriol. J Invest Dermatol 2003, 121:1306-1311.

23. Sa SM, Valdez PA, Wu J, Jung K, Zhong F, Hall L, Kasman I, Winer J, Modrusan Z, Danilenko DM, Ouyang W: The effects of IL-20 subfamily cytokines on reconstituted human epidermis suggest potential roles in cutaneous innate defense and pathogenic adaptive immunity in psoriasis. J Immunol 2007, 178:2229-2240.

24. Kragstrup TW, Otkjaer K, Holm C, Jorgensen A, Hokland M, Iversen L, Deleuran B: The expression of IL-20 and IL-24 and their shared receptors are increased in rheumatoid arthritis and spondyloarthropathy. Cytokine 2008, 41:16-23.

25. Sakurai N, Kuroiwa T, Ikeuchi H, Hiramatsu N, Maeshima A, Kaneko Y, Hiromura K, Nojima Y: Expression of IL-19 and its receptors in RA: potential role for synovial hyperplasia formation. Rheumatology (Oxford) 2008, 47:815-820.

26. Hsu YH, Chen WY, Chan CH, Wu CH, Sun ZJ, Chang MS: Anti-LL-20 monoclonal antibody inhibits the differentiation of osteoclasts and protects against osteoporotic bone loss. J Exp Med 2011, 208:1849-1861.

27. Ogilvie AL, Luftl M, Antoni C, Schuler G, Kalden JR, Lorenz HM: Leukocyte infiltration and mRNA expression of IL-20, IL-8 and TNF-R P60 in psoriatic skin is driven by TNF-alpha. Int I Immunopathol Pharmacol 2006, 19:271-278.

28. Heydendael VM, Spuls PI, Opmeer BC, de Borgie CA, Reitsma JB, Goldschmidt WF, Bossuyt PM, Bos JD, de Rie MA: Methotrexate versus cyclosporine in moderate-to-severe chronic plaque psoriasis. $N$ Engl J Med 2003, 349:658-665.

29. Tak PP, Thurkow EW, Daha MR, Kluin PM, Smeets TJ, Meinders AE, Breedveld FC: Expression of adhesion molecules in early rheumatoid synovial tissue. Clin Immunol Immunopathol 1995, 77:236-242.

30. Haringman JJ, Vinkenoog M, Gerlag DM, Smeets TJ, Zwinderman AH, Tak PP: Reliability of computerized image analysis for the evaluation of serial synovial biopsies in randomized controlled trials in rheumatoid arthritis. Arthritis Res Ther 2005, 7:R862-R867.

31. Antoni CE, Kavanaugh A, Kirkham B, Tutuncu Z, Burmester GR, Schneider U, Furst DE, Molitor J, Keystone E, Gladman D, Manger B, Wassenberg S, Weier R, Wallace DJ, Weisman MH, Kalden JR, Smolen J: Sustained benefits of infliximab therapy for dermatologic and articular manifestations of 
psoriatic arthritis: results from the Infliximab Multinational Psoriatic Arthritis Controlled Trial (IMPACT). Arthritis Rheum 2005, 52:1227-1236.

32. Mease PJ, Kivitz AJ, Burch FX, Siegel EL, Cohen SB, Ory P, Salonen D, Rubenstein J, Sharp JT, Tsuji W: Etanercept treatment of psoriatic arthritis: safety, efficacy, and effect on disease progression. Arthritis Rheum 2004, 50:2264-2272

33. Mease PJ, Gladman DD, Ritchlin CT, Ruderman EM, Steinfeld SD, Choy EH, Sharp JT, Ory PA, Perdok RJ, Weinberg MA: Adalimumab for the treatment of patients with moderately to severely active psoriatic arthritis: results of a double-blind, randomized, placebo-controlled trial. Arthritis Rheum 2005, 52:3279-3289.

34. Rebholz B, Haase I, Eckelt B, Paxian S, Flaig MJ, Ghoreschi K, Nedospasov SA, Mailhammer R, Debey-Pascher S, Schultze IL, Weindl G, Forster I, Huss R, Stratis A, Ruzicka T, Rocken M, Pfeffer K, Schmid RM, Rupec RA: Crosstalk between keratinocytes and adaptive immune cells in an IkappaBalpha protein-mediated inflammatory disease of the skin. Immunity 2007, 27:296-307.

35. Tohyama M, Hanakawa Y, Shirakata Y, Dai X, Yang L, Hirakawa S, Okazaki H, Sayama K, Hashimoto K: The Th17 cytokine IL-22 induces IL-20 production in keratinocytes: a novel immunological cascade with potential relevance in psoriasis. Eur J Immunol 2009, 39:2779-2788.

doi:10.1186/ar4038

Cite this article as: Lebre et al:: Expression of IL-20 in synovium and lesional skin of patients with psoriatic arthritis: differential response to alefacept treatment. Arthritis Research \& Therapy 2012 14:R200

\section{Submit your next manuscript to BioMed Central} and take full advantage of:

- Convenient online submission

- Thorough peer review

- No space constraints or color figure charges

- Immediate publication on acceptance

- Inclusion in PubMed, CAS, Scopus and Google Scholar

- Research which is freely available for redistribution

Submit your manuscript at www.biomedcentral.com/submit 